\title{
Vzdělávání metodou e-learningu podporující regionální spolupráci a vytváření evropského vzdělávacího prostoru v interdisciplinární oblasti životního prostředí
}

\author{
Jana Dlouhá, Jiří Dlouhý, Andrew Barton \\ Envigogika 2010/V/3- Recenzované články/ Reviewed Papers
}

Publikováno/Published 28. 12. 2010

DOI: http://dx.doi.org/10.14712/18023061.56

\begin{abstract}
Abstrakt:
Tento text přináší stručný přehled zkušeností s e-learningovou metodou použitou $\checkmark$ rámci mezinárodní sítě spolupráce univerzit, které společně budují otevřený evropský výukový prostor a poskytují tak platformu pro rozvoj interdisciplinárních a mezikulturních poznatků a zkušeností nezbytných pro porozumění udržitelnosti na evropské úrovni. Spolu $s$ teoretickou reflexí použité metodologie umožňuje tato analýza její všeobecné a široké využití $v$ různých kontextech $v$ rámci vysokoškolské výuky, a také potenciální zapojení dalších regionálních subjektů, což může přispět $\mathrm{k}$ ustavení regionální formy spolupráce a její institucionalizaci jakožto Regionálního centra expertízy (RCE).
\end{abstract}

\section{Klíčová slova:}

Higher education, e-learning, sustainable development competences, social learning, communities of practice, methods, tools and assessment of learning outcomes and processes

\begin{abstract}
:
In the sphere of higher education, the ability to communicate and collaborate across the boundaries of a nation, culture and discipline is one of the basic competences required for sustainable development. A multi-dimensional approach that addresses both the academic community and local/regional actors and decision-makers is needed, and thematic networks of diverse regional partners are often built to cooperate on practical issues that require particular expertise and/or have a learning dimension. Because of this network character, the complex issue of sustainable development can be inter-related to the use of information and communication technologies (ICT) and tools, and virtual collaborative learning used as an ideal learning environment to develop trans-boundary abilities, so that the participants experience differences in perspective in a very direct way and have to come to a joint solution of any given problem.
\end{abstract}

This article presents a brief review of experiences in e-learning used within an international network of cooperating universities with the vision to promote an open European Learning Space and provide a platform for interdisciplinary and intercultural knowledge and experience required to understand sustainability at the European level. Together with a theoretical reflection upon the theme, this analysis should permit generalized and extended usability of the e-learning methodology across diverse contexts 
of higher education, and potentially include other regional institutions to support the establishment of a regional partnership within Regional Centers of Expertise (RCE).

\section{Key words:}

Vysokoškolské vzdělání, e-learning, kompetence pro udržitelný rozvoj, sociální učení, koncept "komunit praxe"; metody, nástroje a evaluační postupy pro hodnocení procesů a výsledků učení 
Povaha vzdělávání pro udržitelný rozvoj je komplexní, a protože v něm jde především o možnost příštího uplatnění poznatků $v$ praxi, např. v různých oblastech a úrovních politiky, a jejich proměnu $v$ efektivní strategie přinášející praktické výsledky, musí tento typ vzdělávání předjímat zapojení různých společenských subjektů při řešení sdílených problémů. To $v$ praxi zahrnuje nejen instituce vědy a výzkumu, vysoké školy (jejichž úlohou je školit budoucí managery a ty, kdo rozhodují v rozmanitých oblastech společenského života, a kdo utvářejí veřejné mínění), ale také regionální partnery z podnikové sféry, nevládní neziskové organizace a všechny, kteří se angažují $\checkmark$ rozvojových procesech $v$ daném regionu. $V$ takovém př́padě jde pak o multidimenzionální proces, $v$ němž všichni tito hráči spolupracují $v$ rámci tematicky orientovaných sítí na praktických problémech, přičemž vysokoškolské instituce zpravidla přispívají svým know-how a expertizou. Proces této spolupráce a vzájemné výměny informací pak zahrnuje dimenzi učení (při řešení společných problému se všichni vzájemně učí); pro samotnou vysokoškolskou výuku znamená kladení vyššího dưrazu na rozvoj schopnosti komunikace a kooperace přes kulturní, národní a oborové hranice, a to především s ohledem na rozvoj kompetencí pro podporu udržitelného rozvoje.

Díky povaze učení v sítích může být výuka komplexní problematiky udržitelného rozvoje založena na využití informačních a komunikačních technologií (ICT) a nástrojů, a virtuální prostředí sloužit jako ideální prostor pro spolupráci například i v mezinárodním měřítku, kdy účastníci výuky tohoto typu získají přímou zkušenost s kulturními a názorovými rozdíly a možnostmi nalezení společných řešení za této situace (Gregou, 2008: 6-7)

Tento text přináší stručný přehled zkušeností s e-learningovou metodou použitou v rámci mezinárodní sítě spolupráce univerzit, které společně budují otevřený evropský výukový prostor a poskytují tak platformu pro rozvoj interdisciplinárních a mezikulturních poznatků a zkušeností nezbytných pro porozumění udržitelnosti na evropské úrovni. Spolu s teoretickou reflexí použité metodologie umožňuje tato analýza její všeobecné a široké využití v různých kontextech v rámci vysokoškolské výuky, a také potenciální zapojení dalších regionálních subjektů, což může přispět k ustavení regionální formy spolupráce a její institucionalizaci jakožto Regionálního centra expertízy (RCE).

\section{Výchozí bod: koncept udržitelnosti ve vědě a vzdělávání}

O trvale udržitelném rozvoji se diskutuje na různých úrovních od roku 1980; tento koncept je důsledkem uznání odpovědnosti za život budoucích generací a touhy vytvořit globální rámec pro politické akce. Jde o nový přístup, který, kromě změn $v$ mnoha oblastech sociálního života, jako například v mezinárodních vztazích, změnil také oblast vědy a vzdělávání - jejich předmět nabyl komplexní a interdisciplinární charakter, a vznikly nové metody výuky a výzkumu, jejichž cílem je sledovat přičinné vztahy v rámci interakce člověka s př́rodou a poskytovat údaje pro tvorbu politik. Objevily se nové obory a jiné musely přehodnotit své př́stupy: vědecké úsilí v interdisciplinárních oblastech se zaměřilo na hodnotově založené a sociálně orientované cíle. Pro naplnění těchto sociálních funkcí bylo potřeba ve vědeckém diskursu zohlednit též "nevědecké" názory zúčastněných aktérů, nalézt nové formy dialogu, který se vede již přes hranice vědy samotné a bere $v$ úvahu pluralitu diskursů, a do vědeckého př́stupu integrovat do určité míry též etickou perspektivu (viz Ravetz, 2006).

Tyto trendy byly $v$ souladu $s$ demokratizačními tendencemi $v$ oblasti vědy, které se uskutečňují v průběhu posledních desetiletí (Müller, 2009) a vedou též ke (skutečným nebo jen potenciálním) změnám v oblasti vysokoškolského vzdělávání, a to nejen s ohledem na kvantitativní růst vzdělávacích programů $v$ souvislosti $s$ rostoucím počtem disciplín, ale také z hlediska uplatňovaných metod vzdělávání a tvorby nového vzdělávacího prostředí, které otevírá možnosti komunikace různých subjektů a podporuje dialog o různých tématech i řešení společných problémů. Proces otevírání našich univerzitních pracovišt́ pro dialog s kolegy z jiných oborů, a pro další zainteresované 
subjekty za hranicemi akademické sféry, vedl k postupné proměně principů vysokoškolské výuky (aniž by nutně znamenal naprosté popření principů dosud platných) - a tyto změny je třeba správně reflektovat.

\section{Principy změn ve vzdělávání - situované a sociální učení}

Uplatňování principů udržitelného rozvoje ve vzdělávání klade nové požadavky na výstupy vzdělávacích procesů, které často kontrastují se současnou vzdělávací praxí: k rozvoji kompetencí, které jsou pro klíčové trvale udržitelný rozvoj, je zapotřebí "nové vzdělávací kultury" podporující rozvoj osobnosti - z tohoto pohledu se člověk má naučit vyrovnávat se složitými situacemi, reflektovat svou činnost, rozhodovat (se), brát na sebe odpovědnost a při jednání zvažovat etické zásady i důsledky svých akcí. Rozvíjení těchto kompetencí podstatných pro udržitelný rozvoj lze dobře uskutečnit i $v$ rámci interdisciplinárního a multikulturního dialogu (Barth et al, 2008: 35) a na rostoucí potřebu sociální interakce a komunikace je tak zaměřena řada strategických politických dokumentů vzdělávání pro udržitelný rozvoj (VUR), které určují řadu kompetencí v různých doménách učení (kognitivní, afektivní, konativní) a vyčleňuji i zvláštní oblast pojmenovanou "učit se žít a pracovat společně", která by mohla být klasifikována jako nová doména sociálního učení - viz (UNECE, 2008) a tab. 2 in: (Dlouhá, 2009).

Sociální sférou se ve vztahu k učení teoreticky zabývají různí autoři ${ }^{1}$, vymezují perspektivu, ve které Ize sledovat proces učení v úzké souvislosti se zapojením jedince do světa sociálních vztahů (a jeho postavením v tomto světě); učení se pak odehrává mj. $\checkmark$ důsledku př́mého vlivu tohoto sociálního prostředí. $Z$ tohoto pohledu byl pak Lavem a Wengerem $v$ roce 1991 navržen pojem sociální učení, $v$ jehož rámci je učení definováno jako "nedílná součást generativní společenské praxe v žitém světě" (Cobb, Bowers, 1999: 35) a pokládáno za otevřený proces bez předepsaných nebo přesně stanovených cílů, pokud jde o jeho výsledky ( $v$ jednotlivých doménách učení). Tato definice byla dále rozvinuta do nehierarchického modelu, který je založen na vzájemné komunikaci (mezi účastníky procesu učení, tedy např. učitelem a žáky), a ve kterém je prostor vymezený plněním úkolů $\mathrm{s}$ předem stanovenými výsledky a nutností dosahovat předepsaných standardů nahrazen prostorem pro kreativní řešení a pro aplikaci teoretických poznatků $\checkmark$ praxi - to je dáno otevřením možností pro situační pochopení, kritické myšlení a rozvoj akčních kompetencí. Tento př́stup je orientován na podporu schopnosti jednat $v$ určitém sociálním prostředí dle vlastních vnitřních norem a zvyklostí.

Sociální učení (základ konceptu, který bude dále použit jako vysvětlující rámec pro využití e-learningové metody), bylo definováno Etienne Wengerem (2000) jako „dynamický, obousměrný vztah mezi lidmi a systémy sociálního učení, na kterých tito lidé participují". Stavebními kameny systémů sociálního učení jsou tzv. komunity praxe, na něž jsou vázány nejdůležitější kompetence utvářející celý systém. $V$ rámci těchto komunit jsou sociálně potřebné kompetence vyjednávány a vytvářeny skrze zkušenost př́mé účasti -

${ }^{1}$ Nové teorie učení vychází z pochopení významu sociální interakce (a jsou tak významné pro účely udržitelnosti), zohledňují aspekty kontextuální, zdưrazňují úlohu hodnot a zájmů, které mají vliv na lidskou činnost, a přesouvají pozornost od péče o jednotlivce a jeho individualitu k sociálním a kulturním faktorům a tzv. situačnímu porozumění (Cobb, Bowers, 1999: 35). Vztah mezi znalostmi a jednáním je definován nově: je vytvořen koncepční rámec pro tzv. "znalosti v akci" díky nimž Ize odpovídajícím způsobem reagovat na danou konkrétní situaci a reflektovat $v$ této reakci i vlastní osobní přesvědčení a záměry („teorie reflexivní akce", viz Schön, 1995, Smith, 2001). Akce je tedy odrazem záměrů (ne již mechanickou aplikací obecně přijatých postupů a metod), a tento aspekt může přinést zásadní změny ve strategických rozhodnutích a preferencích aktérů. Pokud si lidé "uvědomí své skryté pohnutky a mají zájem je přehodnotit", otevírá se možnost učit se společně a je tak vytvořena i scéna pro sociální učení (Loeber, van Mierlo, Grin \& Leeuwis, in: Wals, 2007: 86). 
tedy prostřednictvím zapojení do společného podniku, vyžadujícího, aby členové komunity byli schopni přispět ke společnému cíli, aby spolupracovali, vzájemně se ovlivňovali a současně tuto interakci reflektovali. Tak jsou rưzné formy př́slušnosti k systému sociálního učení definovány jako: zapojení (engagement: jak věci dělat společně), imaginace (imagination: konstrukce obrazu sebe sama, vlastní komunity a jejího místa ve světě) a sladění (alignment: naše aktivity by měly být sladěny $s$ dalšími procesy, standardy nebo požadavky). Sociální učení prostřednictvím této příslušnosti k systému pak přináší jak „osobní transformaci, [tak] i proměnu společenských struktur” (Wenger, 2000).

\section{E-learning v kontextu sociálního učení (a vzdělávání pro udržitelný rozvoj)}

Informační a komunikační technologie (ICT), které jsou velmi účinné z pohledu managementu poznatků a informací, skýtají také značné možnosti z hlediska podpory sociálních interakcí: nově vznikající technologie, zejména Web 2.0 nástroje, mohou být použity k propojení různých sociálních skupin a jejich zapojení do společných (virtuálně realizovaných) projektů. Pokud jsou použity $v$ oblasti vzdělávání, mohou tyto sociální sítě v mnoha aspektech přispět ke změně výukového prostředí a podporovat jeho takzvaný "design orientovaný na studenta", což je přístup charakterizovaný větší autonomií studenta, větším důrazem kladeným na aktivní přístup zahrnující tvưrčí postupy, komunikaci a další participativní strategie učení, a zahrnuje také rozvoj akčních kompetencí, které jsou předpokladem pro efektivní jednání (Allen et al, 2005). Př́kladem Web 2.0 nástrojů je wiki, do níž uživatelé mohou vkládat vlastní příspěvky (texty, obrázky atd.), společně pracovat na stejném textu a jednoduše také vést diskusi k tomuto textu, přičemž jejich motivací je společný zájem na dosažení určitého sdíleného cíle. Tento společný zájem ( $v$ takovém prípadě realizovaný pomocí Web 2.0 nástrojů) také utváří tzv. dynamické komunity učení. Ve výuce je tento přístup využíván $\mathrm{k}$ podpoře tvưrčích schopností, vedení cílených diskusí, realizaci spolupráce, přičemž studenti jsou povzbuzováni k vytváření vlastního obsahu; ze strany učitele je pak žádoucí zaujmout postoj "mentora", podporovat dialog a respektovat individualitu každého účastníka takto pojaté výuky (Wheeler, 2009c). Vzdělávání s využitím sociálních sítí je charakteristické tím, že důraz je přenesen z čistého hromadění faktů k aktivitám v dynamickém prostředí (Downes, 2005); proto je tato metoda velmi dobře využitelná pro rozvíjení kompetencí v oblasti udržitelného rozvoje.

\section{Případová studie: sociální (e-)učení v rámci Evropské sítě vysokých škol}

Evropské univerzity $v$ současné době poskytují četné příležitosti pro virtuální mobilitu studentů v otevřeném (virtuálním) prostoru, který by se mohl stát modelem pro šíreji koncipované sítě spolupráce na různých úrovních vzdělání (nebo i pro další formy učení mimo rámec vzdělávacích institucí). Ve vysokém školství existují takové sítě spolupráce pro trvale udržitelný rozvoj na celoevropské úrovni, např. Virtual Campus for Sustainable Europe (VCSE, viz www.vcse.eu), které jsou založeny na e-learningovém prostředí a nabízejí kurzy zaměřené na udržitelný rozvoj pro vysokoškolské instituce z různých evropských zemí. Poskytují příležitosti pro spolupráci se zahraničními studenty a vytváŕí prostor pro vzájemné kontakty studentư a lektorů z partnerských univerzit, ale také pro zapojení místních „hráčư" zajímajících se o problematiku udržitelnosti.

Obecně mezinárodní sítě spolupráce ve výuce/učení pro trvale udržitelný rozvoj zahrnující (většinou jako nejvýznamnější prvek) vysoké školy jsou často postaveny na regionálních sítích spolupráce různých zainteresovaných stran, které jsou založeny na úzkém propojení mezi akademickými a sociálními aktéry $v$ tzv. komunitách praxe, jejichž společným cílem je přispět $k$ udržitelnosti daného regionu. Nejznámější model takto pojaté regionální spolupráce se rozvíjí s podporou Univerzity OSN - je definován jakožto koncept Regionálních center expertizy (RCE), pro jejichž institucionalizaci platí určitá pravidla (van Dam-Mieras \& Rikers, 2007). V těchto př́padech není sice využití informačních 
a komunikačních technologií nezbytné, avšak umožňuje, usnadňuje a podporuje přenos znalostí mezi různými aktéry. S pomocí ICT a multimédií je možno komunikovat nezávisle na prostorových a časových omezeních, naplňovat rưzné vzdělávací potřeby rozmanitých subjektů, přizpůsobit procesy a strategie učení regionálnímu kontextu, Ize ale také překonat některé institucionální bariéry. Ty jsou často rozhodující pro možnost vedení dialogu přes hranice disciplin a diskursů, což je podstatné zejména $v$ akademickém prostředí. Pro tyto účely jsou virtuální kolaborativní a komunikační technologie vysoce užitečné, často používané; pro učení vytvářejí prostředí, které bývá charakterizováno svou velmi dynamickou povahou (Görsdorf et al, 2008: 73-75).

\section{E-learningové kurzy v rámci sítě VCSE}

Pro analýzu využití e-learningové metody výuky v rámci sítí vysokých škol a dalších zúčastněných subjektů Ize aplikovat teorie sociálního učení; jako vysvětlující rámec pro studium procesů učení by pak mohl být použit model komunit praxe. Z tohoto hlediska je komunikace ve vysokoškolském prostředí sice založena na tradičních zásadách akademického dialogu (souvisejících s procesem peer-review, v němž je "vyjednávána" a zajištována nejen kvalita př́spěvků do tohoto dialogu, ale také jejich význam), učení však probíhá nelineárně, je realizováno ve třech formách odpovídajících konceptu komunit praxe: prostřednictvím zapojení (do výzkumné činnosti, odborného dialogu), imaginace (jakožto reflexe vlastní role $v$ této komunikaci, způsobu zapojení a jeho důsledků) a sladění (s ohledem na uznávaní autority a přijaté postupy) (viz Wenger, 2000). To však odpovídá hlavním cílům vysokoškolského vzdělávání, jimiž je uvést studenty do akademického diskursu; studijní programy jsou běžně navrhovány s ohledem na tento cíl zahrnují nejen přednášky zajištující transfer znalostí, ale i výzkumné aktivity pod vedením zkušených členů komunity. Studijní prostředí je modelem reálné situace ve vědě, a má být dostatečně flexibilní, aby odráželo postupné změny a zvyky ve skutečné akademické obci, k nimž dochází s ohledem na prosazování principů udržitelného rozvoje: například zvýšení úlohy mezioborové komunikace a vznik nových pojmů, významů, či oborù v hraničních oblastech.

Následující příklady z praxe tohoto typu výuky jsou založeny na zkušenostech s konkrétními vysokoškolskými kurzy, které se konaly v rámci evropské sítě vysokých škol zaměřené na problematiku udržitelného rozvoje (VCSE); přinášejí možnosti zobecnění a srovnání s příslušnými teoriemi sociálního učení. Metodika e-learningu je $v$ nich popsána od fáze designu kurzu, výběru tématu a předmětu, volby vzdělávacích cílů a nástrojů (relevantních pro e-learning), až k popisu procesů učení, formulaci požadavků a nároků na jejich plnění, vysvětlení role aktérů, až po fázi posouzení a hodnocení studijních výsledků a získání nezbytné zpětné vazby.

\section{Box 1: Př́padová studie e-learningové výuky - kurz MPG\&SD}

Kurz Multiple Perspectives on Globalization and Sustainable Development (MPG\&SD), organizovaný Centrem pro otázky životního prostředí UK, běžel v evropském zimním semestru 2009/2010. Výuka byla součástí mezinárodní sítě VCSE a účastnili se jí studenti z Německa a České republika. Jednalo se o distanční kurz (plně e-learningový) a plánovaná zátěž byla 150 hodin (5 kreditů). Dvanáct studentů kurz úspěšně ukončilo, z pưvodního počtu 15ti, kteří si jej zapsali. Téma Globalizace bylo vybráno kvůli jeho komplexní a interdisciplinární povaze, která umožnila studentům zkoumat problematiku z různých disciplinárních pohledů - pochopit souvislosti sociální, ekonomické, a environmentální, včetně managementu prírodních zdrojů aj. aspektů, a také si uvědomit praktické důsledky globalizačních procesů (především díky tomu, že v dialogu byli zapojeni odborníci pracující mimo akademickou pưdu, jejichž úkolem bylo projednat téma se studenty).

V tomto kurzu bylo rozhodnuto využít konceptu sociálního učení, na jeho bázi navrhnout metodu výuky založenou na vytvoření vhodného vzdělávacího prostředí simulujícího nejdůležitější vlastnosti komunit praxe, a vyvinout tak model, který by do 
procesu učení integroval sociální interakce, jež mají zásadní význam pro komunikační praxi $v$ akademickém světě a projevují se jako zvyklosti a normy pro psaní odborných textů.

\subsubsection{Design kurzu Multiple Perspectives on Globalization and Sustainable} Development (MPG\&SD)

Jako první krok byl vytvořen výukový model založený na konceptu komunit praxe, který měl vyvolat žádoucí procesy sociálního učení. Design kurzu pak zahrnoval následující kroky a principy:

1. Vytvoření vzdělávacího prostředí.

2. Založení sociálních vazeb, a neustálá podpora i reflexe těchto interakcí během procesu učení.

3. Uvědomění si vlastních osobních hodnot a názorů na problematiku před začátkem učení; následné vyjednávání o sdíleném porozumění v průběhu společné činnosti.

4. Zavedení pravidel, která je třeba dodržovat - založených na akademických principech a postupech.

5. Zahájení procesu učení a jeho průběžná reflexe.

6. Výběr společného konkrétního tématu či projektu, které všichni účastníci procesu výuky budou aktivně zkoumat ve vzájemné spolupráci.

7. Návrh hodnotících postupů, které zohlední výkon studentů jak z hlediska výsledků jejich práce, tak také z hlediska celkového prínosu pro vzdělávací komunitu.

8. Komunikace o výsledcích kurzu, jejich analýza a vyhodnocení - to vše ve vzájemném dialogu studentů a jejich učitelů.

\subsubsection{Téma (předmět)}

Témata pro výuku udržitelnosti by měla být pokud možno komplexní a interdisciplinární natolik, aby je bylo možno uchopit z různých disciplinárních pohledů, kriticky posuzovat a komunikovat o nich, a to i mezi různými společenskými subjekty, kteř́ mohou prakticky přispět $k$ řešení problematiky udržitelnosti. Ve výuce by tak kromě poskytování relevantních výukových materiálů (zahrnujících texty zakotvené v různých disciplínách) měly být navrženy problémově orientované úkoly, po studentech požadováno vyhledávání vlastních zdrojů informací a metodických řešení daných úkolů. Některé další učební cíle (např. rozvíjení hodnotově založených postojů) by se měly stát rovněž součástí individuální studijní cesty.

Tváří v tváŕ rozmanitosti oborových prístupů studenti sice zažívají nejistotu, ale současně musí hledat cestu vpřed - tato metoda výuky je velmi důležitá pro práci ve virtuálním prostředí, které je bohaté na informace, ale jinak v něm chybí orientační záchytné body a metodické vedení.

\subsubsection{Zaměření (metoda)}

Problémově orientované učení je základním principem vzdělávání pro udržitelný rozvoj; někteří autoři $v$ jeho rámci vymezují př́stup zvaný rozvíjení akademické gramotnosti (academic literacy practice - jeho cílem je socializace $v$ akademickém prostředí), kdy jsou studenti př́mo zapojeni do procesů čtení a psaní textů relevantních pro danou disciplínu, čímž získávají nové znalosti ve svém oboru relativně nezávisle (Lea \& Street, 1998). Proces akademického psaní představuje možný způsob př́mého zapojení do 
akademické komunity: tento přístup využívá odborný dialog (který utváří principy a metody dané akademické disciplíny), který je modelován za kontrolovaných podmínek pod dohledem učitele. Vyučovací metodou je pak tzv. mentorování (podpora nezávislého rozvoje odborného i osobnostního), jehož podstatou je společný zájem na výsledcích a výstupech učení a pro něž je důležitá souhra všech účastníkư vzdělávacího procesu, jejich spolupráce na tvorbě výsledku $v$ rưzných rolích (autoři, recenzenti, atd.). Taková výuka/učení úzce souvisí s úlohou prostředí, v němž se učení odehrává, a skládá se ze dvou přístupů: on-line výuky a on-line komunikace.

\section{Box 2: Výukové cíle}

Studium v rámci kurzu je zaměřeno na rozvoj tři druhů gramotnosti environmentální gramotnosti či gramotnosti pro udržitelný rozvoj, gramotnosti akademického psaní, a gramotnosti v oblasti ICT. Environmentální gramotnost či gramotnost pro udržitelný rozvoj souvisí s tématem kurzu a studenti se mají dozvědět se o problémech životního prostředí a politik udržitelného rozvoje velmi obecně, a dále pak studovat téma dle vlastního výběru do větší hloubky. Gramotnost akademického psaní je považována za důležitou metakognitivní dovednost nezbytnou ke splnění úkolu psaní textu. Studenti by měli projít všechny fáze procesu akademického psaní, přičemž vývoj jejich textů od jednoho stádia k dalšímu je důležitým kritériem pro závěrečné posuzování (zatímco výsledek jejich práce, „produkt”, je považován spíše za experimentální text, na nějž nejsou kladeny př́sné požadavky z hlediska obsahu a zaměření, nicméně by měl splňovat základní akademické standardy). ICT gramotnost je základním předpokladem a také vedlejším produktem učení. Vzdělávací cíle ve všech těchto třech oblastech tak zahrnují komplexní kompetence v oblasti „vyšší úrovně myšlení" a také rozvoj dalších domén učení (nejen kognitivní, ale i afektivní a konativní), přičemž akční kompetence, kterými se vakademickém prostředí rozumí výzkumné dovednosti, jsou jedním z nejdůležitějších vzdělávacích cílů. Musí být ovšem dodržována pravidla a formální zvyklosti v oblasti výzkumu a akademického psaní, přičemž se zdůrazňuje tvưrčí a kritický př́ístup.

V kurzu MPG\&SD byly písemné práce studentů, které byly hlavními "produkty" kurzu, umístěny ve studentském wiki prostoru. Na závěr kurzu z nich učitel sestavil tzv. Globalization Handbook, společnou virtuální publikaci, která je k dispozici pro budoucí "generace" studentů a může jim sloužit jako výchozí bod (náhled této publikace viz (Dlouhá, 2010)).

\subsubsection{Výukové prostředí}

Ve vzdělávání pro udržitelný rozvoj je důležitá role výukového prostředí: může pomoci zdưraznit interdisciplinární aspekty procesu učení, podporovat aktivní učení, přístupy a řešení. Těchto cílů Ize dosáhnout díky více fluidní povaze virtuálního prostoru, který nabízí různé způsoby, jak procházet jeho obsah, díky interaktivnímu charakteru, a multi-dimenzionální struktuře (odkazy otevírají související témata). Na druhou stranu, virtuální výukové prostředí (VLE) použité v e-learningu mưže být užitečné také pro účely správy poznatků a informací, strukturování času, poskytování online zdrojů a z hlediska požadavků na organizaci kurzu. Všech těchto cílů nemůže být dosaženo obvykle pouze v rámci Learning Management System (LMS), a tedy v praxi mnoho učitelů použíá sice některý z dostupných LMS jako např́klad Moodle, ale kombinují jej alespoň částečně s využitím sociálních sítí a jejich nástrojů, jako jsou Facebook a wiki, atd. To Ize také vřele doporučit, protože nad rámec (poměrně restriktivních) funkcí LMS poskytují sociální sítě mnoho příležitostí ke spolupráci a tvưrčímu přístupu. 


\section{Web 2.0}

Sociální rozměr procesu učení Ize dobře simulovat pomocí nástrojů Web 2.0, které jsou označovány jako sociální web. Umožňují vytvářet, kontrolovat (editovat) a také zveřejnit informace samotnými uživateli, a to ve vzájemné spolupráci a na demokratickém základě. Mezi oblíbené a snadno využitelné Web 2.0 nástroje patři např́klad wiki ${ }^{2}$ - soubor vzájemně propojených webových stránek, které může jednoduše editovat kdokoli. Web 2.0 umožňuje kolektivní práci na textu, jeho úpravy i diskuzi týkající se obsahu, a také srovnávání různých variant a případné návraty $\mathrm{k}$ "historicky starším" verzím textu (to je důležité vzhledem $\mathrm{k}$ veřejné povaze wiki prostoru a související hrozbě vandalizmu). Po technické stránce poskytuje tento software nesčetné možností pro tvorbu textů, vkládání obrázků a grafů, propojování s dalšími zdroji četnými hyperlinky atd.

\section{Historie Web 2.0}

Web 2.0 je souhrnným pojmem pro nové, emergentní vlastnosti webu, které na rozdíl od pưvodního Web 1.0 (který poskytoval poměrně pasivní zkušenost s Internetem) vznikly z potřeby propojit lidi, sdílet znalosti a zkušenosti, a poskytnout nové možnosti pro výuku/učení. Sociální software ${ }^{3}$ obecně umožňuje číst i přispívat do webových prostor a požadavek aktivní participace je jeho základní charakteristikou. Některé z nástrojů, které Web 2.0 poskytuje, nabízejí prostředí zvláště vhodné pro kolaborativní formy učení, kde studenti jsou do procesu učení aktivně zapojeni. Učení se zde odehrává v sociální interakci a dialogu, v jeho rámci všichni zúčastnění včetně učitelů spolupracují, kladou otázky, rozvíjejí společně argumenty a závěry, a v těchto aktivitách se angažují rovným dílem (dochází tak k proměně role učitele). Tyto Web 2.0 nástroje jsou tak potenciálně vhodné pro výuku především s ohledem na rozšíření spektra pěstovaných kompetencí (kritický př́stup, spolupráce, aktivní tvorba) (Wheeler, 2009b). ${ }^{4}$

\section{Wiki}

Wiki je soubor webových stránek, které dovolují uživatelům přidávat vlastní obsah (podobně jako diskusní fóra, blogy aj. Web 2.0 nástroje), a také současně umožňuje ostatním uživatelům tento obsah editovat. Co odlišuje wiki od jiných redakčních systémů, je fakt, že jednotlivé stránky mohou být vzájemně propojeny a uspořádány zcela libovolně, nejsou publikovány $v$ pořadí dle času nebo taxonomické či jakékoli jiné předem dané hierarchie. To činí z wiki velmi pružný systém - jde o prostorové struktury, které jsou nekonečně expandovatelné. Nabízejí možnost průběžné úpravy či aktualizace stránek (jejich soustavného vývoje) a současně obsahují četné nástroje, jak sledovat historii těchto

\footnotetext{
2 Slovo je odvozeno z hawaiské fráze Wiki wiki, což znamená rychlý - v rámci IT terminologie je wiki rychlé a také uživatelsky jednoduché publikační médium (Wheeler, 2009)

3 Zahrnuje populární aplikace jako blogy, wiki a podcasting; sociální sítě jako Facebook a Myspace; služby pro foto- a video-sdílení jako např. Flickr a YouTube; známé nástroje jako RSS feeds, sociální tagging (např. Delicious), mikroblogy (např. Twitter), geotagging; a další. Mezi Web 2.0 Ize zařadit i sítové hry a simulace jako je Second Life, nebot' těží ze sociálních dimenzí a charakteristik sdílených prostorů v sociálním Webu. (Wheeler, 2008a) Sociální software jako wiki založený na participaci nabízí možnosti jako značkování, hlasování, verzování, hyperlinkování and vyhledávání, a také diskusi a komentování (Schwartz, 2003).
}

${ }^{4}$ Z pedagogického hlediska zde probíhají následující děje či procesy (Wheeler, 2009b):

Sdílení: sdílení a porovnávání informací mezi studenty (těmi, kdo se učí)

Zkoumání: hledání nekonzistencí a rozdílů ve významech

Vyjednávání: společná dohoda o významu $\rightarrow$ společná konstrukce poznání

Testování: zkoušení a modifikace syntetických poznatků, společně konstruovaného poznání

Formulace: formulace dohodnutého a nově vytvořeného významu. 
stránek a porovnávat jejich různé verze. Navíc editační prostředky wiki jsou velmi jednoduché, nevyžadují znalosti relativně komplikovaného HTML jazyka, takže uživatelé jsou schopni pracovat $v$ tomto prostředí bez předchozí zkušenosti s tvorbou webových stránek (Duffy et al., 2006).

Specifikem wiki softwaru je jeho interaktivita, otevřenost pro simultánní spolupráci na podobných tématech. Wiki jsou široce využívány pro výukové účely ve světě, jsou přirozeným nástrojem pro dálkové vzdělávání, umožňují vytvářet interaktivní úkoly a také ovšem zveřejňovat studijní materiály - často mají charakter předmětně zaměřených encyklopedií. Někdy jsou vytvářeny jako společné zásobárny informací či expertizy nezbytné pro řešení praktických problémů v rámci společenství. Pak mohou přispívat ke vzniku tzv. "komunit praxe" - mají totiž rysy podporující jejich úspěšné fungování: nabízejí možnosti interakce, snadnou účast založenou na demokratických principech, poskytují zajímavý obsah, jsou napojeny na širší předmětnou oblast, utvářejí osobní a komunitní identitu a interakci, zajišt'ují vlastní rozvoj v čase (Schwartz et al, 2003).

Tato softwarová aplikace se navíc v průběhu času stává soběstačná z hlediska dohledu nad svým obsahem; pro studium poskytuje svobodu tvořit vlastní příspěvky a využívat individuální studijní cestu. Je prokázáno, že studenti se v rámci sdíleného prostoru a společných cílů vzájemně podporují - spolupracují totiž právě proto, aby si vzájemně poskytli radu nebo vedení (Wheeler, 2008a). Výzkumy realizované na téma užitečnosti využití wiki ve výuce ukázaly též na možný př́nos této metody pro rozvoj kritického myšlení, analytických schopností; jako přednost se jevila veřejná publikace výsledku (větší péče věnovaná detailưm, posílení vědomí autorství i odpovědnosti s tím související) i lepší organizace procesu učení (plné soustředění se na určité téma jakožto elementární složku celku znalostí). Každopádně se ale zvýšilo vědomí "sounáležitosti" (autorů jednotlivých) příspěvků a jejich obsah se přizpưsobil společnému tématu nebo cíli - posílila se tak komunita učících se. Výsledkem práce bylo vyšší sebevědomí studentů (posílené možností diskuze, sebevyjádření), zlepšilo se kritické hodnocení zdrojů a studenti měli větší radost z práce; ve výuce si pak studenti především zvykali na samostatnou a společnou práci bez prímého dohledu autority. Nevýhody jsou uváděny následující: nedostatečná pravidla či "etiketa" práce ve wiki např. při editaci cizích textů nebo vzhledem k uznávání autorství, nízká strukturovanost procesu psaní a učení, v některých případech strach z experimentování ve veřejném prostoru. Na druhé straně museli studenti často vytvářet ad hoc strategie $\mathrm{k}$ překonání nejistot a potíží práce $\mathrm{v}$ nezvyklém prostředí. Zvýšení kvality (odborných) textů vytvořených studenty v závislosti na míře jejich využívání wiki je předmětem dalšího výzkumu. (Wheeler, 2009a, 2009b, 2008b).

Proces učení v prostředí wiki se odehrává v následujících stadiích či stupních, které Ize charakterizovat nestejnou mírou kooperace (Wheeler, 2009b):

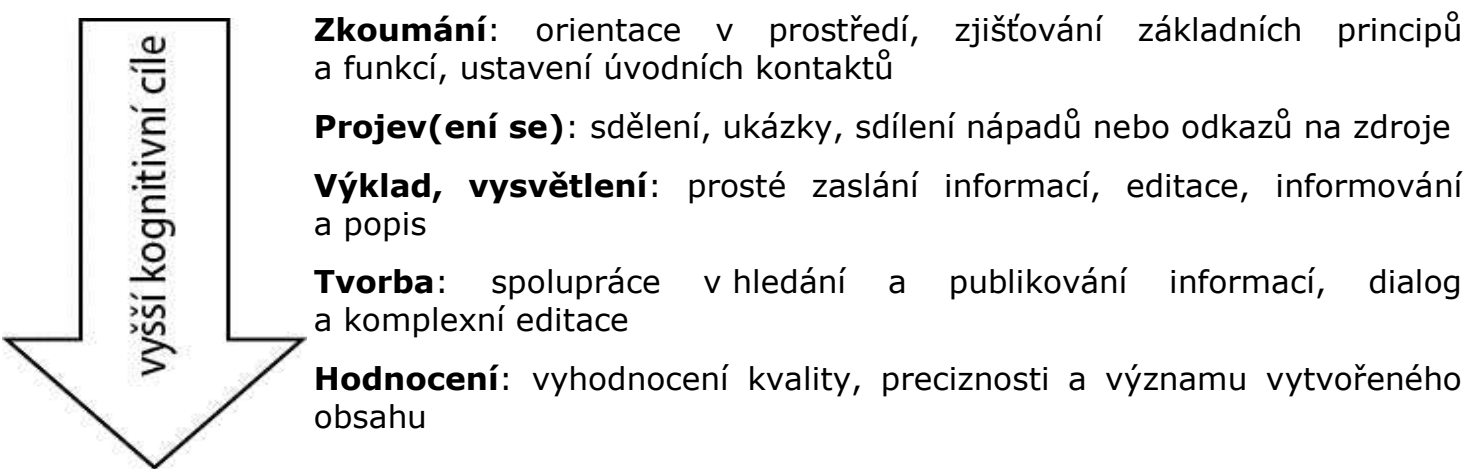


Z hlediska sociální dimenze učení je důležité, že vyšší míra spolupráce je nezbytná právě pro dosažení vyšších kognitivních cílư.

\section{Box 3: Výukové prostředí v kurzu MPG\&SD}

Kurz MPG\&SD byl plně realizován ve virtuálním prostředí a byl založen na následující e-learningové strategii, která je relevantní pro VUR na univerzitní úrovni: použití 1) Moodle Learning Management System (LMS) pro primární orientaci studentů, a umístění základních návodů a technických manuálů (pro podporu zvládání ICT), a 2) wiki prostředí Mediawiki, které na základě principů sociálního učení vytváří otevřený prostor pro tvưrčí práci studentů v rámci kurzu: tito zde píší své texty na zadaná témata, diskutují o jejich obsahu a dělí se o své názory (o tom již bylo referováno v (Dlouhá \& Macháčková-Henderson, 2008; Dlouhá \& Dlouhý, 2009)). Wiki prostředí bylo navrženo lektory k stimulaci metakognitivních dovedností (manuály pro odborné psaní a další návody jsou zde k dispozici), organizaci procesu psaní (wiki př́spěvek byl popsán jako žánr, takže při psaní Ize postupovat $v$ dobře definovaných krocích); současně slouží jako model akademického prostředí (nabízí prostor pro diskusi a proces peer review v diskusní části každé stránky) a poskytuje také evidenci procesu psaní (historie stránky může sloužit pro analýzu postupu studentů a jejich př́stupu ke zpracování textu). Hlavní část požadované práce byla provedena ve wiki: studenti sem psali své akademické eseje a později také komunikovali navzájem o jejich obsahu a kvalitě; jejich texty a hlavně též recenze tam pak zůstaly pro př́padné využití budoucími generacemi studentů.

Př́kladem práce studentů ve wiki prostoru mohou být jejich texty dostupné online ve studentské wiki, viz např. esej o biodiverzitě.

\subsubsection{Pravidla a požadavky}

$\checkmark$ daném rámci (založeném na konceptu komunit praxe) a problémově orientovaném výukovém prostředí získávají studenti modelovou zkušenost s akademickým diskursem a zásadami komunikace $v$ obci výzkumných pracovníků: toto prostředí se vyznačuje velkým rozsahem možností (existuje zde svoboda volby výzkumného tématu), ale také specifickými pravidly (normami výzkumu a etiky psaní; požadováno je dodržování kritických postupů vzájemného hodnocení, naplňování formálních požadavků atd.) a omezeními (nutnost postupně vymezit úzké téma svého zájmu a pokračovat disciplinovaně a efektivně směrem k podloženým závěrům). Výukové cíle by měly odrážet žádoucí kompetence a tomu by měl odpovídat též způsob jejich prokazování/hodnocení na základě odvedené práce např. formou portfolií (jež mohou obsahovat např. diskusní příspěvky ve fórech v Moodlu, studentské práce a vzájemné posudky ve wiki), nikoli tedy pomocí on-line testování, které je v takových případech téměř zbytečné (a Ize je také obtížně spravedlivě ohodnotit: v distančním vzdělávání není možné při práci na testu zajistit samostatnou práci jednotlivých studentů).

\subsubsection{Procesy učení}

Procesy učení, které je zaměřeno na udržitelný rozvoj, by měly být otevřené, vycházet z konstruktivistických principů, být součástí vlastní studijní cesty studenta (v zadání by měl být vyžadován nezávislý studentský výzkum v oblasti vlastního tématu či zájmu). Učení by samo o sobě mělo mít povahu reflexivní (poskytovat příležitosti k diskusi ve všech fázích procesu) a transformativní: výběr tématu by měl být založen na osobních hodnotách studentů; další výzkum tohoto (interdisciplinárního) tématu a jeho kritické vnímání (z různých úhlů pohledu) pak může pưsobit na změnu hodnotového systému. Interaktivní procesy učení, které ovlivňují studenta a mají vliv též na učitele, jsou důležitým aspektem tohoto přístupu - vzájemné působení žáků a jejich učitelů je výsledkem společného zájmu na konečném výsledku práce a odráží se v její kvalitě.

Důležitou roli plní komunikace - mělo by být požadováno, aby se studenti dohodli na určitém názoru, a výsledkem této dohody by mělo být společné rozhodnutí o některých (reálných nebo hypotetických) problémech. Vzájemné posuzování prací (proces peer review) pak využívá možností komunikace v rámci procesu posuzování: hraje roli při vyjednání použitých kritérií kvality. 
Ve virtuálním prostoru je k dispozici evidence probíhající komunikace (ve fórech nebo v diskuzní části wiki) a historie tvorby textů (ve wiki prostředí v historii stránky); Ize tak vysledovat jejich vzájemnou závislost nebo jednotlivé fáze procesů psaní a tato možnost slouží jako zdroj dat pro další výzkum procesů učení; tato data Ize použít pro jejich analýzu.

Příklad diskusní části stránky (studentského textu - odborné eseje), kde je umístěno peer review napsané kolegou a hodnocení učitele viz např. diskuse k eseji o biodiverzitě.

\subsubsection{Role aktérů}

Učení $v$ sítích vyžaduje zapojení aktérů $v$ relativně volném, formálním nebo neformálním systému vzájemných vztahů s cílem vzájemného poznávání a výměny zdrojů informací (Görsdorf et al, 2008: 67). To platí i pro e-learningové prostředí, kde všichni účastníci využívají možnosti sdílet informace, vyjasňují si své postoje a hodnoty, a vzájemně se podporují při dosahování (více či méně společných) cílů. Učitelé poskytují studentům podporu v celém procesu jejich samostatného "výzkumu" (hrají roli spíše mentorů, než instruktorů), podporují interaktivní komunikaci mezi účastníky nebo také otevírají možnost komunikace s externími odborníky, pomáhají precizovat kritický pohled studentů, a podněcují dobré úmysly a vzájemné porozumění na obou stranách. Dưležitým aspektem e-learningu je, že učební prostředí hraje též roli "autority" stejně jako učitelé (viz Box 4).

\section{Box 4: Výzkum role aktérů v kurzu MPG\&SD}

V kurzu MPG\&SD se konkrétní cíle různých aktivit prováděných $v$ rámci učení odrážely $\checkmark$ měnících se rolích studentů $v$ průběhu procesu učení (vystupovali jakožto výzkumníci, pisatelé odborných textů, recenzenti atd.). Také role lektorů a externích odborníků, kteří se do kurzu zapojili, nebyly přesně definovány - chovali se podle okolností jako učitelé, instruktoři, poradci, hodnotitelé práce studentů, ale i jejich kolegové (hlavním faktorem pro zajištování kvality byl proces peer-review, který se vztahoval na všechny zúčastněné). $V$ e-learningu jsou všichni aktéři také $v$ neustálé interakci s vzdělávacím prostředím - toto prostředí je často nejen zdrojem informací a základem organizace kurzu, ale také faktorem při změně rolí účastníků. Jak prokázal výzkum provedený v rámci MPG\&SD, elektronické prostředí (systém Moodle) sám pomáhal sledovat studentské aktivity, nebo kontrolovat množství a termíny odevzdání úkolů, a tak ovlivňoval projevy autority v procesu učení. Celkový závěr tedy byl, že postavení učitelů a tím i formy jejich autority jsou formovány virtuálním vzdělávacím prostředím, které má některé téměř neviditelné pravomoce, a tak nahrazuje některé funkce autority, kterou učitelé používají při interakci tváŕí v tvář (Dlouhá M., 2010).

\subsubsection{Role hodnocení a spektrum použitých nástrojů}

Podle pedagogických teorií by různé faktory, které hrají roli v procesu učení, měly být mezi sebou sladěny: nejen cíle a obsah, ale také "design" úloh a hodnocení jejich

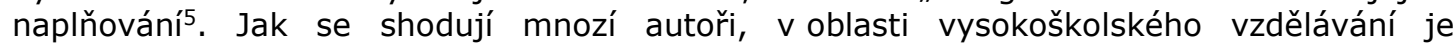
nejčastěji nesladěným faktorem právě hodnocení, a „většina přístupư k hodnocení má tendenci soustředit se spíše na to, co je snadné měřit, než co je důležité." Nejlepší metody hodnocení výsledků učení v oblasti vysokoškolského vzdělávání se zaměřuji na "kritické myšlení, řešení problémů, tvořivost, zvídavost, etické otázky" nebo na "šíři a hloubku odborných znalostí". Věnovat pozornost těmto faktorům je požadavkem aktivního, konstruktivistického pedagogického prrístupu, ale $v$ praxi se ve většině případů hodnotí na

\footnotetext{
${ }^{5}$ Reeves (2006) deklaruje, že: „Úspěch učení v jakémkoli vzdělávacím prostředí ... je určen tím, do jaké míry je je sladěno osm nejdůležitějších faktorů výuky: 1) cíle, 2) obsah, 3) „design instrukce", 4) úkoly pro studenty, 5) role lektora, 6) role studenta, 7) technologické nástroje (v e-learningu), a 8) hodnocení."
} 
základě testů založených na výběru z více možností, znalostních zkoušek nebo podle obsahu požadovaného textu (eseje) na určité téma (Reeves, 2006).

Pokud si chceme při hodnocení výsledků učení na vysoké škole stanovit poněkud náročnější cíle, je třeba zohlednit nejen tyto zjevné výsledky, ale reflektovat též samotný proces učení, a to jak ze strany učitelů, tak samotných studentů. "Techniky" takového posuzování zahrnují vzájemné hodnocení (peer-review), sebe-hodnocení, autentické hodnocení a další sofistikované metody. To vše vyžaduje, aby studenti byli schopni posoudit práci stejného druhu, jaká je požadována i po nich, a tím také získávají zkušenosti s hodnocením v praxi (Sadler, 2005). Kromě toho si musí uvědomit a přijmout určitá hodnotící kritéria, která jsou tím pádem transparentní a studenti je mohou aplikovat i na svůj výkon.

\section{Box 5: Metody hodnocení v kurzu MPG\&SD}

Vzdělávací cíle v kurzu MPG\&SD byly zaměřeny na dovednosti a kompetence potřebné pro sebe-regulaci procesu učení, jako např́klad: pochopení, kritický úsudek, komplexní myšlení (uvědomění si interdisciplinárního kontextu), etika vědecké práce, a přijetí konstruktivistických, akčně orientovaných strategií učení (jejich uplatnění v teorii a praxi). Cíle hodnocení byly orientovány na proces učení, nikoli jeho výsledek; možnosti posuzování byly podle těchto cílů upraveny a úzce souvisely s kritérii kvality práce studentů a jejich textů - odborné eseje, ale i všechny další příspěvky ve fórech byly pečlivě analyzovány $v$ každé fázi procesu jejich tvorby.

Pro konkrétní účely hodnocení uvedené výše musí pak být vyvinuty nové nástroje jako je například hodnotící tabulka6 - které představují kvalitativní techniku hodnocení umožňující posoudit, do jaké míry je dosaženo vzdělávacích cílů, především kompetencí (souvisejících s udržitelností) demonstrovaných v průběhu učení i v jeho výsledcích.

\subsubsection{Zpětná vazba - percepce studentů}

Percepce kvality kurzů vedených formou e-learningu na akademické úrovni ze strany studentů silně souvisí ( $v$ souladu s příslušnými závěry výzkumu) s jejich přśstupy $k$ učení v rámci daných kurzů, které jsou založeny na jejich obecných preferencích a strategiích učení. Pro úspěch e-learningu je tento druh informací důležitou zpětnou vazbou z hlediska rozvíjení metody výuky i jejího praktického využití. Dnes už existuje metodologie výzkumu, která umožňuje získat vypovídající data formou dotazníkových šetření, a to poměrně rutinně i na malém vzorku respondentů (pro reprezentativní vzorek již byly tyto metody ověřeny a vyhodnoceny na velkých souborech dat - viz též $(E T L, 2010))^{7}$. Prístup

\footnotetext{
${ }^{6}$ Hodnotící tabulka je běžný nástroj hodnocení - pokud byste hledali termín na Googlu, zobrazí se vám více než 15 mil. odkazů, z nichž většina (z prvních výsledků) má vzdělávací konotace a mnohé z nich nabízejí užitečné př́klady, nebo dokonce nástroje pro vývoj hodnotících tabulek pro vlastní vzdělávací účely. Definice tohoto pojmu na Wikipedii (2010) je následující: „Hodnotící tabulka (rubric) je nástroj pro bodování [určitých výsledků učení] v rámci subjektivně pojatého hodnocení. Jedná se o soubor kritérií a hledisek souvisejících se vzdělávacími cíli, kterých se používá pro posouzení výkonu studenta při tvorbě textů, realizaci projektů, psaní esejí a v dalších úkolech. Hodnotící tabulka umožňuje standardizované hodnocení podle stanovených kritérií, takže bodování výsledků práce je pak jednodušší a transparentnější. Hodnotící tabulka je také pokusem o důsledné vymezení posuzovacích kritérií. To umožňuje jak učitelům, tak i studentům posoudit hodnotící kritéria, která jsou v těchto prípadech komplexní a subjektivní, a také poskytnout základ pro sebe-hodnocení, reflexi a peer review".
}

7 Jsou k dispozici psychometrické metody měření na základě dotazníků, například standardizovaný Dotazník zkušeností s výukou a učením (Experiences of Teaching and Learning Questionnaire, ETLQ). Průzkum percepcí studentů je obvykle založen na závěrečném dotazníkovém šetření pomocí 5-bodové 
k učení je definován jako kombinace motivů a strategií uplatňovaných studenty; tyto přístupy jsou klasifikovány jako „povrchní", "hluboké" a „zaměřené na dosažení výsledkư" (přičemž existují motivy a strategie používané $v$ každé z těchto kategorií - povrchní motivy, povrchní strategie, atd.) (Biggs, 1987: 14-19). Výzkum prokázal, že přístupy studentů k učení mohou výrazně ovlivnit tento proces učení (z hlediska jeho účinnosti) a mají dopad na jejich konečný výkon. Současně tyto přístupy ale nejsou neměnné, závisí na individuálních preferencích, vnímání vzdělávacího prostředí, motivaci, pracovním zatížení a jiných faktorech; hodnocení těchto přístupů pak otevírá možnosti pro ovlivňování procesu učení i výsledného úspěchu studentů změnou vzdělávacího prostředí a prostřednictvím různých intervencí učitele. Výsledky takových výzkumů mohou být použity také pro sumativní hodnocení kurzu, zatímco jiné metody, jako je záznam učení (viz Barth et al, 2008: 41) jsou vhodnější spíše pro formativní hodnocení.

\section{Závěr - použití pojmu sociální učení ve vysokoškolském vzdělávání metodou e-learningu se zaměřením na rozvoj kompetencí pro udržitelný rozvoj}

Představená metoda e-learningu je modelovým př́kladem využití konceptu sociálního učení ve vysokoškolském vzdělávání s cílem rozvíjet kompetence $v$ oblasti udržitelného rozvoje. $V$ takovém typu výuky/učení se studenti učí prostřednictvím sociálního prostředí, $v$ našem př́padě podporovaného prostředím elektronickým. Způsob jejich zapojení do vzdělávacího procesu by se měl rídit obecnými zásadami platnými (pro komunikaci) $\vee$ rámci akademické obce, přičemž by současně měly být zohledněny mírné posuny, které zde nastaly s ohledem na prosazování konceptu vzdělávání pro udržitelný rozvoj).

Použitý př́stup vycházející z teorie komunit praxe umožňuje rozvíjet sociální kompetence a interakce, které jsou životně důležité pro dosažení cílů sdílených členy komunity, $v$ niž se učení odehrává ( $v$ našem případě studentů). Tento koncept by měl být dále rozpracován pro vysokoškolské vzdělávání $v$ oblasti udržitelného rozvoje, nebot' otevírá možnost dosáhnout změn ve vzdělávacích přistupech a metodách (a nakonec i paradigmatech vzdělávání jako takového), vzít v úvahu sociální funkce vědy a vzdělávání, konkrétně interdisciplinární, komplexní a hodnotově orientovanou povahu jejich předmětu a metody.

E-learningová metoda poskytuje řadu nástrojů pro vytvoření vlastního virtuálního výukového prostředí, které významně přispívá $\mathrm{k}$ dosažení těchto cílů vzdělávání - i když obrovská rozmanitost a dynamický vývoj ICT nástrojů znemožňuje, aby je autoři tohoto textu všechny prozkoumali. Kurzy organizované $v$ rámci regionální $a / n e b o$ mezinárodní sítě vzdělávacích institucí byly prezentovány jako specifický příklad využívající modelu komunit praxe $\vee$ oblasti vzdělávání: byly analyzovány zkušenosti s výstavbou kurzů, jejich realizací i reflexí $v$ rámci formativního i sumativního hodnocení. $V$ předvedeném prípadě mělo virtuální výukové prostředí klíčovou úlohu nejen jako systém řízení poznatků a informací (knowledge management system), ale $\mathrm{i}$ jako otevřený prostor, $v$ němž jsou $\mathrm{k}$ dispozici nástroje a prostředky sociální komunikace, které nejen podporují sítě vztahů, ale často samy hrají roli "aktérü" v procesu učení.

Na předvedeném příkladu bylo ukázáno, že sociální webové nástroje by mohly sloužit k naplnění určitých vzdělávacích cílů v oblasti udržitelného rozvoje: jsou dostatečně

Likertovy škály ( $v$ rozsahu od Rozhodně nesouhlasím $=1$ bod po Naprosto souhlasím $=5$ bodů), a měři míru souhlasu či nesouhlasu s výroky týkajících se zkušeností studentů '(Richardson, 2009; $E T L, 2010)$. 
flexibilní a nabízejí možnosti pro aktivní a tvưrčí přístup, spolupráci a interakci, v níž jsou role účastníků často (re)definovány. Navíc tyto technické nástroje poskytují evidenci, prostřednictvím které Ize procesy učení průběžně sledovat a dokumentovat, reflektovat a následně analyzovat: například příspěvky účastníků ve wiki prostoru, kde je možno sledovat historii jejich vzniku, nebo diskusní fóra v Moodlu, která nabízejí př́ležitost sledovat sociální aspekty "vědecké" spolupráce a uplatněných zásad akademického dialogu - distribuci autority, možnosti dialogu přes hranice disciplin, přidanou hodnotu komunikace v multikulturním prostředí apod.

Vliv virtuálního vzdělávacího prostředí na procesy učení se mưže potenciálně předmětem dalšího výzkumu a možné výzkumné otázky mohou být následující: Jaká je role e-learningu $v$ rámci vzdělání orientovaného na problematiku udržitelnosti? Mohl by pojem situované poznání (situated cognition) být využit též $v$ př́padě učení v e-learningovém prostředí? Jaké jsou další možnosti a nástroje pro aktivní práci studentů a jejich komunikaci, které by braly $v$ potaz kulturní, oborové a další bariéry? Jaké jsou nástroje pro hodnocení vhodné pro tento typ a uspořádání výuky?, a mnoho dalších.

Metodika výuky prostřednictvím simulovaného zapojení do (akademické) komunity, přijetí pravidel tohoto diskursu a jejich aplikace v modelu "komunity praxe" představovalo unikátní vzdělávací zkušenost, kterou bylo možné realizovat pouze díky využití e-learningového prostředí $v$ rámci multikulturní a interdisciplinární mezinárodní sítě spolupráce mezi evropskými univerzitami (VCSE). V tomto společném vzdělávacím prostředí (budovaném ovšem na odlišných přístupech jednotlivých zapojených institucí), bylo pravidlem odlišné vnímání tématu a způsobu výuky/učení ze strany jak studentů, tak také učitelů (tutorů), což následně umožnilo kriticky přemýšlet o cílech výuky/učení, jejich metodách a principech.

Využití metody výuky pomocí e-learningu zohledňujících sociální aspekty výuky je zároveň jednou z možností, jak postupně uvádět v život proměny vědeckého diskurzu, k nimž dochází v souvislosti s prosazováním cílů a principů udržitelného rozvoje do vzdělávací praxe - $\mathrm{k}$ těmto změnám patři například zvýšení povědomí o možnostech spolupráce rozličných zainteresovaných stran ( $v$ důsledku čehož Ize vytvářet transdisciplinární prostředí též v pedagogické praxi, tj. např́klad do výuky na vysokých školách zapojit subjekty mimo akademické prostředí), využití hodnotově orientovaných prístupů ve vědě, a spolupráce v sítích partnerů směřujících $k$ cílům, které jsou sjednány ve vzájemném dialogu. Zkušenost s e-learningovou metodou přinášející inovace vzdělávací praxe (na vyšších úrovních vzdělání) mưže být široce využita, a přinést, spolu s určitým technologickým pokrokem, například také rozšíření demokratických zásad otevřeného dialogu a prosadit i cíle orientované k udržitelnosti do širšího vzdělávacího systému, tedy nejen na vysokoškolské úrovni.

\section{Literatura}

- Allen, J., Ramaekers, G., Velden, R. van der., (2005) Measuring Competencies of Higher Education Graduates. In D. J. Weerts \& J. Vidal (Eds.), Enhancing Alumni Research: European and American Perspectives, New Directions for Institutional Research. Number 126 (pp. 4959). Jossey-Bass, San Francisco.

- Barth, M., Burandt, S., Pizzera, J. Görsdorf, E., (2008) Strategies for developing and running e-courses for the VCSE. In VCSE Best Practice Guidebook, Virtual Campus for Sustainable Europe, $2008 . \quad$ Retrieved from http://www.czp.cuni.cz/vcsewiki/index.php/VCSE Best Practice Guidebook

- Biggs, J. B. (1987). Student Approaches to Learning and Studying. Research Monograph. Australian Council for Educational Research Ltd. . Australia: Radford House.

- Cobb, P., \& Bowers, J. (1999). Cognitive and situated learning perspectives in theory and practice. Educational researcher. Educational researcher, 28(2), 4-15. Retrieved from 
http://edr.sagepub.com/cgi/doi/10.3102/0013189X028002004 http://dx.doi.org/10.3102/0013189X028002004

- van DAM-MIERAS, M. C. E., \& Rce, R. J. (2007). Rhine-Meuse: towards learning for sustainable development. Journal of Education for Sustainable Development, 1(1), 51-60. Retrieved from http://jsd.sagepub.com/cgi/doi/10.1177/097340820700100111 http://dx.doi.org/10.1177/097340820700100111

- Dlouhá, J., Dlouhý, J., (2009) Use of Wiki Tools for Raising the Communicative Aspect of Learning. In D. Remenyi (Ed.), Proceedings of the 8th European Conference on e-Learning. NR Reading: Academic Conferences Ltd. (pp. 165-173). .

- Dlouhá, J. (2010). Globalisation Risks and Opportunities. VCSEWiki. . Retrieved from http://www.czp.cuni.cz/vcsewiki/index.php?title=Globalisation Risks and Opportunities\&oldi $\underline{d=1350}$

- Dlouhá, J., \& Macháčková Henderson, L., (2008) E-learning as an opportunity for virtual mobility and competence development within European Universities. In Williams, R. Remenyi, D. (Ed.), The Proceedings of the 7th European Conference on e-Learning (ECEL). Book 1 (pp. 297-307). : NR Reading: Academic Publishing Limited.

- Dlouhá, J. (2009). Kompetence v environmentálním vzdělání. Envigogika, 4(1), Retrieved from http://www.envigogika.cuni.cz/envigogika-2009-iv-1/kompetence-v-environmentalnimvzdelani cs\# ftn5

- Dlouhá, M. (2010). Autorita ve virtuálním vzdělávání (Authority in virtual education). Praha: UK, FSV, ISS.

- Downes, S. (2005). E-Learning 2.0. eLearn Magazine, Retrieved from http://www.downes.ca/post/31741

- Duffy, P., Bruns, A, The Use of Blogs, Wikis and RSS in Education: A Conversation of Possibilities. In Proceedings Online Learning and Teaching Conference 2006 (pp. 31-38). . Retrieved from http://eprints.qut.edu.au/5398/

- $\quad$ ETL, Enhancing Teaching-Learning Environments in Undergraduate Courses . . Retrieved from http://www.etl.tla.ed.ac.uk/publications.html

- Görsdorf, E., Mader, C., Pizzera, J., Zimmermann, F., Creating regional (e)learning networks. In VCSE Best Practice Guidebook, Virtual Campus for Sustainable Europe, 2008. . Retrieved from http://www.czp.cuni.cz/vcsewiki/index.php/VCSE Best Practice Guidebook

- Gregou, S. Introduction. In VCSE Best Practice Guidebook, Virtual Campus for Sustainable Europe, 2008. 2 Retrieved http://www.czp.cuni.cz/vcsewiki/index.php/VCSE Best Practice Guidebook

- Lea, M. R., Street, B. V, . Student writing in higher education: An academic literacies approach. Studies in higher education, 23(2), 157-172.

- Loeber, A., van Mierlo, B., Grin, J., \& Leeuwis, C. (2007) The practical value of theory: conceptualising learning in the pursuit of a sustainable development. In A. E. Wals (Ed.), Social Learning toward a more Sustainable World: Principles, Perspectives, and Praxis. : Wageningen Academic Publishers.

- Müller, K. (2009) Cesty rozvoje mezioborových vztahů ve vědě a jejich sociální zdroje. In J. Dlouhá (Ed.), Vèdění a participace. Teoretická východiska environmentálního vzdèlání (pp. 101-110). Praha: Karolinum.

- Ravetz, J. R. (2006). Post-normal science and the complexity of transitions towards sustainability. Ecological Complexity, 2006(3), 275-284. Retrieved from http://linkinghub.elsevier.com/retrieve/pii/S1476945X07000037 http://dx.doi.org/10.1016/j.ecocom.2007.02.001 
- Reeves, T. C. (2006). How do you know they are learning? The importance of alignment in higher education. International Journal of Learning Technology,2(4), 294-309.

- Richardson, J. T. (2009). Face-to-face versus online tutoring support in humanities courses in distance education. Arts and Humanities in Higher Education,8(1), 69-85. Retrieved from http://ahh.sagepub.com/cgi/doi/10.1177/1474022208098303 http://dx.doi.org/10.1177/1474022208098303

- Sadler, R. D. (2005). Interpretations of criteria-based assessment and grading in higher education. Assessment and Evaluation in Higher Education, 30(2), 175-194. Retrieved from http://www.tandfonline.com/doi/abs/10.1080/0260293042000264262 http://dx.doi.org/10.1080/0260293042000264262

- Schön, D. A. (1995). Knowing-in-action: The new scholarship requires a new epistemology. , 27(6), 26-34.

- Schwartz, L., Clark, S., Cossarin, M., \& Rudolph, J. (2003). . : Athabasca University, Centre for Distance Education, Report no. R27/0311.

- SMITH, M. K. Donald Schön, (2001). Learning, reflection and change. The encyclopaedia of informal education. . Retrieved from http://www.infed.org/thinkers/et-schon.htm

- UNECE Steering Committee on Education for Sustainable Development. The Reporting Format, 2008. (Advance copy of ECE/CEP/AC.13/2008/2/Add.1) . . Retrieved from http://www.unece.org/env/esd/inf.meeting.docs/SC/SC-

3/ece.cep.ac.13.2008.2.add.1.e.AC.pdf

- VCSE (2008). Best Practice Guidebook. . .

- Wenger, E. (2000). Communities of practice and social learning systems. Organization, 7(2),

- Wheeler, S. (2008). All Changing: The Social Web and the Future of Higher Education (a tale of two keynotes) Keynote speech for the Virtual University: Models, Tools and Practice Conference, Technical University of Warsaw, Poland. .

- Wheeler, S., Yeomans, P., \& Wheeler, D. (2008). The good, the bad and the wiki: Evaluating student-generated content for collaborative learning. British Journal of Educational Technology, 39(6), 987-995. Retrieved from http://doi.wiley.com/10.1111/j.14678535.2007.00799.x http://dx.doi.org/10.1111/j.1467-8535.2007.00799.x

- Wheeler, S., \& Wheeler, D. (2009). 2009a) Using wikis to promote quality learning in teacher training. Learning, Media and Technology, 2009, Vol. 34, No. 1, March, 1-10. Learning, Media and Technology, 2009(34), 1-10. Retrieved http://www.tandfonline.com/doi/abs/10.1080/17439880902759851 http://dx.doi.org/10.1080/17439880902759851

- Wheeler, S. (2009). Learning 2.0: How Students Are Using the Social Web in Their Learning. : University of Plymouth e-learning Conference Boundary Changes: Redefining Learning Spaces, 2009. Retrieved from http://www.slideshare.net/timbuckteeth/learning-20-howstudents-are-using-social-software-in-their-learning-presentation

- Wheeler, S. (2009) Destruction and Creativity on the Social Web: Learning with wikis in higher education. In S. Hatzipaganos \& S. Warburton (Eds.), Social Software and Developing Community Ontologies. London: IGI Global Press.

- WIKIPEDIA-contributors, . Rubric (academic) [Internet]. : Wikipedia, The Free Encyclopedia. Retrieved http://en. wikipedia.org/w/index.php?title=Rubric (academic)\&oldid $=377808501$ 


\section{Poděkování:}

Článek vznikl v rámci projektu VaV SP/4h6/142/08 "Návrh aktualizovaných výukových modelů, rozvinutí metody počítačem podporované výuky (e-learning) a zavedení evaluačních mechanizmü pro celoživotní vzdělávání voblasti životního prostředi" ("E-V-Learn") financovaného v rámci v rámci "Resortního programu výzkumu a vývoje $v$ puisobnosti Ministerstva životního prostředí"

Mezi výstupy tohoto projektu jsou metodiky použitelné pro výuku formou e-learningu, které jsou k dispozici online na stránkách Enviwiki: Metodika tvorby textü v otevřeném internetovém prostoru a Metodika využití Wiki (Wiki - metodika). 
Časopis Envigogika vydává Centrum pro otázky životního prostředí UK. Vývoj časopisu je podpořen projektem OP VK Mezioborová sít udržitelného rozvoje.

Více najdete na internetových stránkách projektu mosur.czp.cuni.cz
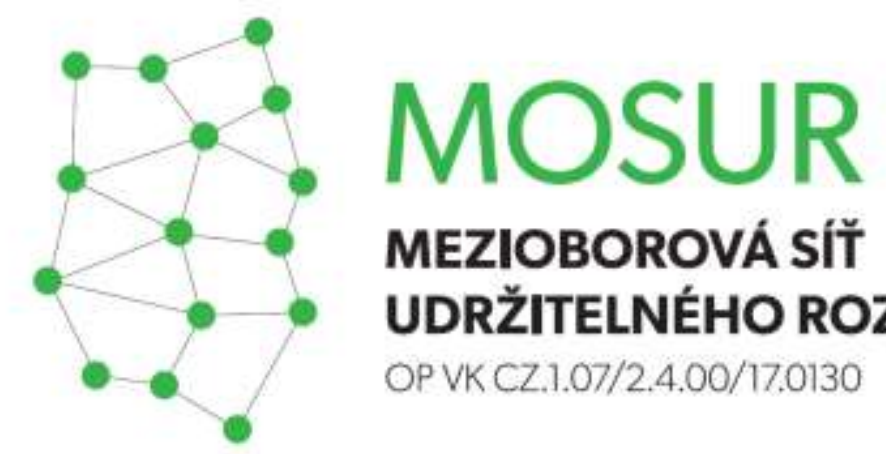

\section{MEZIOBOROVÁ SÍT} UDRŽITELNÉHO ROZVOJE

OP VK CZ.1.07/2.4.00/17.0130
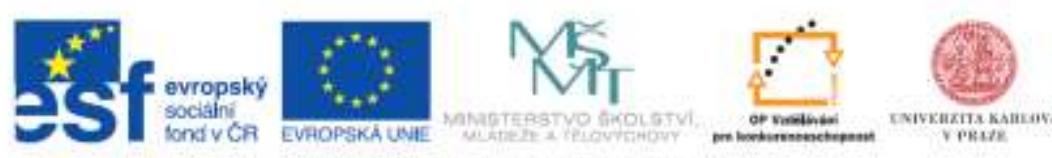

INVESTICE DO ROZVOJE VZDELAVANI 